\title{
MELT-WATER DRAINAGE PATTERN OF COMPOSITE GLACIERS
}

\author{
By KARL N. THOME
}

(Geologisches Landesamt Nordrhein-Westfalen, 4150 Krefeld, West Germany)

\begin{abstract}
Medial moraines and lineations on the surface of composite glaciers enable the detection of structural and hydrological features. A study of the composite glacier Breidamerkurjökull, south Iceland, indicates relationships between subglacial waterways, ice structure in the junction area, and development of the glacier terminus. First, rivers are situated in or near medial moraines because melt water percolates to the bed and moves from there with the subglacial rivers mainly in the direction of ice flow. Secondly, the contact between two feeder glaciers sometimes forms an angle at the glacier terminus. Then the meltwater river escaping from the contact, generally in a radial direction (away from the glacier front), during the retreat will be transferred to the front of the first receding glacier. The drainage of the contact zone then changes from a radial to a tangential direction, destroying the terminal moraines of the recession stages.

Similar relations are found in relics of Pleistocene ice sheets, two examples of which are compared. The huge subglacial channel of the Münsterlănder Kiessandzug-Esker below the ice sheet of the Saalian glaciation in the Münsterland, north-west Germany, was formed in the iceflow direction. It therefore gives details of the morphology and of the great ice-dammed lake east of the Teutoburger Wald ridge. At the contact between the Norwegian and Baltic Sea glaciers, the terminus formed an angle during the maximum extent of the Weichselian glaciation in northern Jutland. During retreat, the Norwegian glacier receded first. The large melt-water river escaping from the contact between both glaciers had formed the huge Karup Sandur during the maximum, but now, during the recession, it changed to the front of the Norwegian ice, destroying the recession moraines there.
\end{abstract}

Résumé. Caractéristiques du drainage de l'eau de fusion pour un glacier composé. Des moraines médianes et des linéations à la surface des glaciers composés permettent de détector les caractères structuraux et hydrologiques. Une étude du glacier composé Breidamerkurjökull, Islande du Sud, indique des relations entre les conduits d'eau sous glaciaires, la structure de la glace dans la zone de jonction et le développement du front du glacier. En premier lieu, les rivières sont à l'intérieur ou à proximité des moraines médianes parce que l'eau de fonte percole vers le lit et de là s'écoule avec le torrent sous glaciaire, généralement dans la direction d'écoulement de la glace. En second lieu, le contact entre deux glaciers adjacents forme quelquefois un angle près du front. Dans ce cas, le torrent d'eau de fonte qui s'échape du contact, généralement dans une direction radiale (loin du front) au cours du recul, va être transféré au front du premier glacier en retrait. Le drainage de la zone de contact varie alors d'une direction radiale à une tangentielle en détruisant les moraines terminales des à stades
de recul.
Des situations semblables se rencontrent dans les reliquats des calottes du pleistocène en deux cas de comparaison. L'immense chenal subglaciaire du Münsterlănder Kiessandzug Esker à la base de la calotte de la glaciation Saaliene du Münsterland au nord ouest de l'Allemagne, a été formé dans la direction d'écoulement de la glace. Cela fournit des précisions sur la morphologie du grand lac barré par la glace à l'est de la chaine Teutoburger Wald. Au contact entre les glaciers Norvégiens et ceux de la Baltique le front forma un angle pendant l'extension maximale de la glaciation Weichseliene dans le Jutland septentrional. Au cours du retrait le glacier Norvégien recula le premier. La grande rivière s'échapant du contact entre les 2 glaciers a formé l'immense Sandur Karup pendant le maximum, mais après lors du recul, elle s'est déplacée vers le front norvégien en y détruisant les moraines.

Zusammenfassung. Abfluss-Muster des Schmelzwassers aus zusammengesetzten Gletschern. Mittelmoränen und Lineationen auf den Oberflăchen zusammengesetzter Gletscher ermöglichen die Entschleierung struktureller und hydrologischer Züge. Ein Studium des zusammengesetzten Gletschers Breidamerkurjơkull in Süd-Island zeigt Beziehungen zwischen subglazialen Wasserwegen, Eisstrukturen, Mittelmorănen und Vorstossgliederung. 1. Subglaziale Ströme liegen meist in oder nahe den Mittelmorănen, weil das Schmelzwasser in ihnen zur Gletscherbasis sinkt und dort sich hauptsăchlich in der Eisfliessrichtung bewegt. 2. Der Kontakt von zwei Nähr-Gletschern bildet manchmal einen Winkel am Gletscherende. Dort entspringt meist ein Schmelzwasserstrom, der radial (vom Gletscher weg) entwăssert. Wăhrend des Eisrückzuges verlegt dieser Strom seinen Lauf vor die Front des zuerst zurückweichenden Teilgletschers und zerstört dessen Rückzugsendmorănen.

Ähnliche Zusammenhănge wurden in Überresten pleistozăner Inlandeise gefunden. Zwei Beispiele werden verglichen. Der Münsterlănder Kiessandzug (Nordwestdeutschland) - ein sehr grosses Os aus der Saale-Vereisung - entstand durch einen subglazialen Kanal, der aus dem grossen Eisstausee des Weserberglandes gespeist wurde. Er ist in Fliessrichtung des ehemaligen Gletschers angelegt und verrăt durch seinen Verlauf noch Bedingungen des Eisvorstosses. Am Kontakt des Norwegischen mit dem Ostsee-Gletscher der Weichselvereisung in Jütland bildete der maximale Eisrand einen einspringenden Winkel, in dem ein Schmelzwasserstrom den Karup-Sander aufschüttete. Wăhrend des Eisrückzuges verlegte der Schmelzwasserstrom seinen Lauf vor die zurückweichende Front des Norwegischen Gletschers, ein deutliches Indiz dafür, dass dieser zuerst zurückwich. 


\section{INTRODUCTION}

Medial moraines will be used here to study the structural peculiarities which affect subglacial and englacia water flow. In temperate glaciers, water accumulates at the base, where its subglacial action is strongly influenced not only by the morphology of the glacier bed but also by the glacial structures imprinted into the ice during its flow over undulating ground.

The connection between glacier flow conditions, the morphology of the glacier bed, and subglacial water in recent glaciers also helps us to understand flow conditions in the Pleistocene ice sheets.

\section{BREIDAMERKURJÖKULL, ICELAND}

This large outlet glacier on the coastal side of the southern slope of Vatnajökull flows from a mountainous area near Öraefajökull down to the sandur plain at the coast of the Atlantic Ocean. It consists of the different ice bodies of several feeder glaciers separated from each other in the mountains by nunataks; they ultimately become united to form one large glacier. The different ice bodies of this glacier can be distinguished very easily by their individual medial moraines.

For the present study it is important that Breidamerkurjokull is not affected nearly as much by volcanic activity as the glaciers to the west of it. The extent of that glacier is sufficiently large to develop different subglacial features side by side. Its terminus at the sandur plain has a front of about $16 \mathrm{~km}$. Between 1700 and 1890 the glacier was mainly advancing, though slowly, with halts and short recessions. After 1890 a great retreat began, which accelerated after the first tens of years and continues until the present time. During the time of this recession large areas of formerly ice-covered land became ice-free and now show the imprint of the activity of both glacier ice and subglacial water.

Geomorphological features due to the glacier in the recession area, combined with reports of occasional visitors (Thorarinsson, 1943; Eythorsson, 1949; Todtmann, 1960; Price, 1969), enable the reconstruction of subglacial waterways and their connection with the structural properties of the glacier, and the situation of the medial moraines on its surface (Fig. 1).

The dating of the $1850-90$ stage is from Thorarinsson (1943), of the 1936 stage from Flosi Björnsson, of Kvisker in Iceland, but the later stages have been determined from air photographs taken in specific years.

The outermost moraine ridges are incised by many more melt-water outlets than the inner later stages in the recession area. The disappearance of many of the melt-water outlets was accompanied by an enlargement of the remaining melt-water channels. This is a consequence of the concentration of melt water during the ice recession, a feature which will be found at almost all receding glaciers which had more than one melt-water outlet at their greatest extent.

At Breidamerkurjökull, it is conspicuous that during its recession most of the melt-water outlets in the eastern part (in ice body No. VI, Fig. 1) disappeared at an early stage, whereas in the western part of the glacier where the ice bodies I-V are situated some of the large melt-water outlets have persisted within or near the medial moraines (meltwater outlets Nos. 2-8) until the present time.

But melt-water outlets Nos. 1 and 10 (Fig. 1), which are situated near the western and eastern glacier flanks, have also persisted. Their permanence can easily be understood because they flow through the thinner, more crevassed parts of the glacier, which receive more heat

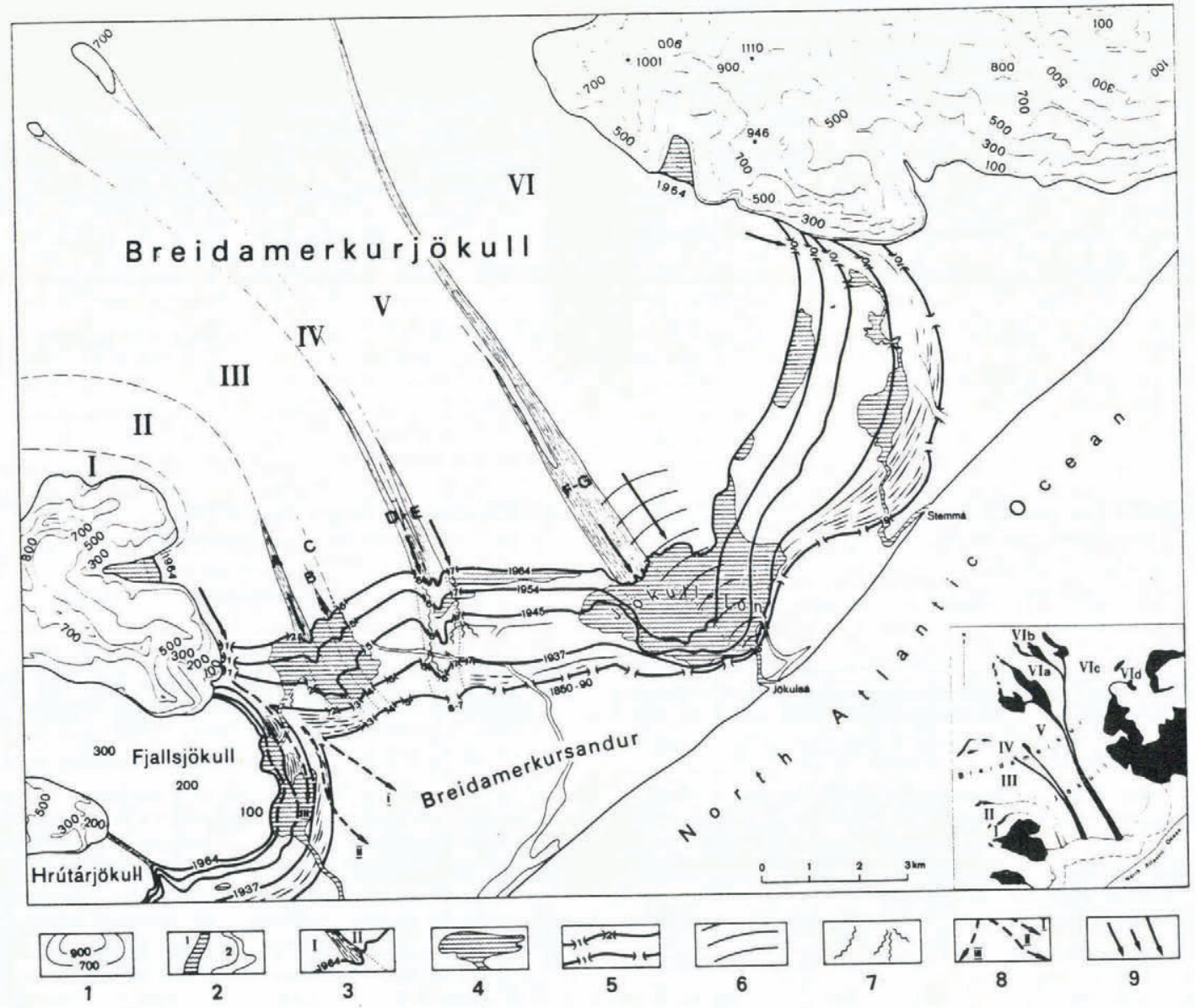

Fig. 1. Breidamerkurjökull, Iceland. 1, mountains, elevation in meters; 2, sandur plain with river beds (1, in action: 2, abandoned); 3 , ice edge about the year .... medial moraine $A-G$, ice bodies of feeder glaciers I-VI; 4, lake; 5, melt-water outlets (some of them with numbers); 6 , undirvarp; 7, esker; 8 ,

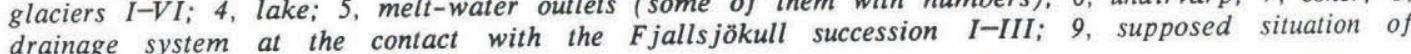
subglacial and englacial melt-water channels. 
from the adjacent rock slopes. Therefore, glacier flanks are places for the preferential development of subglacial rivers. Almost all large glaciers with their termini on plains have water outlets along their flanks.

Persisting melt-water outlets at the terminus, but far away from the glacier flanks, arise in or near medial moraines. Their positions in relation to these moraines seem to have been constant during the recession since 1890 .

A good example of this is medial moraine $\mathbf{D}-\mathbf{E}$ (Fig. 1 ), where eskers and abandoned melt-water channels in the recession area can be related to the outflow of melt water at the glacier terminus. Price (1969) has given a detailed description of this area. There are similar configurations of medial moraines and melt-water outlets near medial moraines $A-B-C$. There is only one large melt-water outlet (No. 5 in Fig. 1) which is not situated within a clearly visible medial moraine, but it is always at a constant distance. Also, the largest outflow from Breidamerkurjökull, the river Jökulsá (No. 8 in Fig. 1), is situated at a constant distance east of a medial moraine ( $\mathrm{F}-\mathrm{G}$ in Fig. 1). Jonsson (1955) described the situation during the years 1927-28. At that time, the glacier was still in contact with its outermost moraine ridges near the river Jökulsá, which could not be crossed because it was too turbulent; the glacier was therefore used for crossing. Around the Jökulsa outflow the glacier surface was considerably lowered. This lowering around melt-water outlets is also well known from other glaciers. In Iceland it is called "undirvarp" (Ahlmann, 1938, Jónsson, 1955). Jónsson explained it as due to subglacial erosion by the melt water, which causes the glacier to sink into the erosion hole.

After 1930, when the ice edge near Jökulsá receded from the outermost moraine ridge, a lake (Jökulsarlon) formed and the subglacial outflow of Jökulsá at the ice edge was hidden below the surface of the lake. However, during the recession the undirvarp always remained at the same position in relation to the adjacent medial moraines $F-G$ on the receding glacier terminus. Even until today it marks the position of subglacial erosion below the glacier.

The existence of constant melt-water outlets near the flanks of large glaciers helps to explain the melt-water conditions near medial moraines because they are contact zones between the lateral parts of feeder glaciers within them. There must be a connection between medial moraines and persisting melt-water outlets. It can be understood by a study of their development.

In the junction area between feeder glaciers (Fig. 2), behind nunataks or valley slopes, where lateral moraines become medial moraines, the melt water cannot usually flow over the glacier surface because it is inclined to the nunatak or the rock slope. In some cases a lake will form. Crevassing of the ice near rock slopes enables melt water to penetrate into the ice, where most of it finds its way to the glacier bed. The water cannot freeze in a temperate glacier and normally it cannot flow in any direction other than that of the ice flow. If the quantity of subglacial water is sufficiently large, it will form a subglacial river or, if not, it will become trapped in a chamber which moves down-stream with the ice to the glacier terminus. Because new water chambers are always developing in the junction area, they form a row of water chambers in the ice-flow direction. When these chambers approach the terminus, increased melting connects them to subglacial or englacial channels.

Subglacial channels also occur at a constant distance from medial moraines. In such cases, the melt water can flow beneath the base of the glacier away from the contact zone of the feeder glaciers, if the slope of the valley floor is sufficiently steep. The water is then trapped at a constant distance from the junction area and flows from there in the ice-flow direction.

\section{Development of Breidamerkurjökull between advance and
recession}

Glaciers smaller than Breidamerkurjökull advance or retreat in all parts almost as one unit, but the large Breidamerkurjokull, which consists of a number of ice bodies derived from different feeder glaciers, shows a more complex reaction in different parts of its terminus.
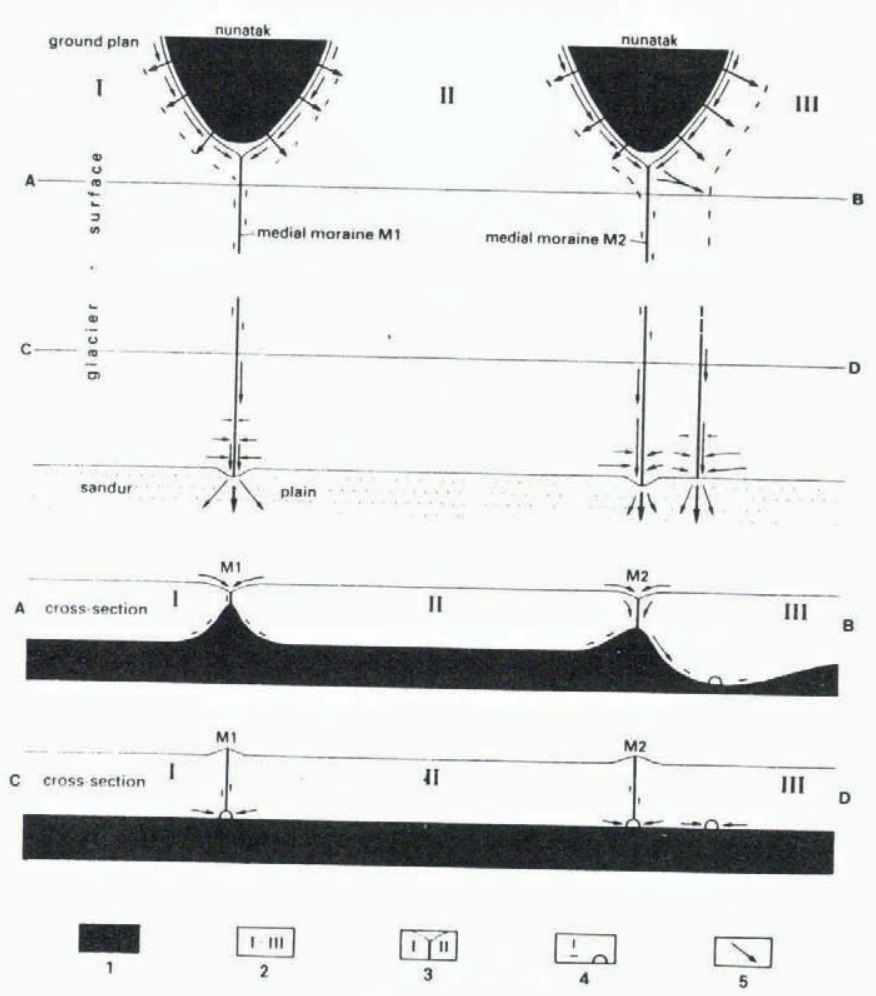

Fig. 2. Medial moraines, and subglacial and englacial waterways in a composite glacier. 1, glacier base; 2 , ice bodies, separated by nunataks and medial moraines; 3 , lateral and medial moraines $M 1, M 2 ; 4$, subglacial and englacial water in chambers and channels; 5, water flow into and out of the glacier.

The outermost terminal moraine of Breidamerkurjökull has two spectacular curved bows where the glacier almost reached the Atlantic Ocean (Fig. 1).

The eastern bow is drained by the river Stemma and the western one by the river Jökulsá. Here, the one bow will be called "Stemmar bow" and the other "Jökulsar bow".

The latest advance in the "Jökulsar bow" seems to have occurred after the ice edge west of it had already halted, because the strike of the moraine ridges west of the "Jökulsar bow" meets the strike of that bow at an angle.

The ice receded from the "Jökulsar bow" in about 1930 (Jónsson, 1955), but it had already receded from the "Stemmar bow" many years previously. The difference between the times of latest advance and first retreat in these two bows also seems to coincide with the subglacial development between advance and recession in Breidamerkurjökull.

"Stemmar bow" was the outermost centre of the early advance. It is situated in the centre of the largest ice body (No. VI in Fig. 1) without medial moraines. The melt-water outlets of that bow changed their positions and disappeared early in the recession, while the melt-water outlet Jőkulsá increased in size by the concentration of several subglacial rivers. This concentration of subglacial melt water in the area around Jökulsá seems to have activated the final advance in that part of the glacier, whereas all other parts of the glacier had already become static. This can be readily understood in the light of Jonsson's explanation for the development of the undirvarp. Subglacial erosion deepened the glacier bed, increasing water supply diminished the viscosity of the glacier, and this resulted in acceleration of the ice flow.

Junction between Breidamerkurjökull and Fjallsjökull

At the beginning of the eighteenth century the advancing Fjallsjökull became united with the advancing Breidamerkurjokull on the sandur plain. During the recession, these glaciers became separated about 1940 (Thorarinsson, 1943). 

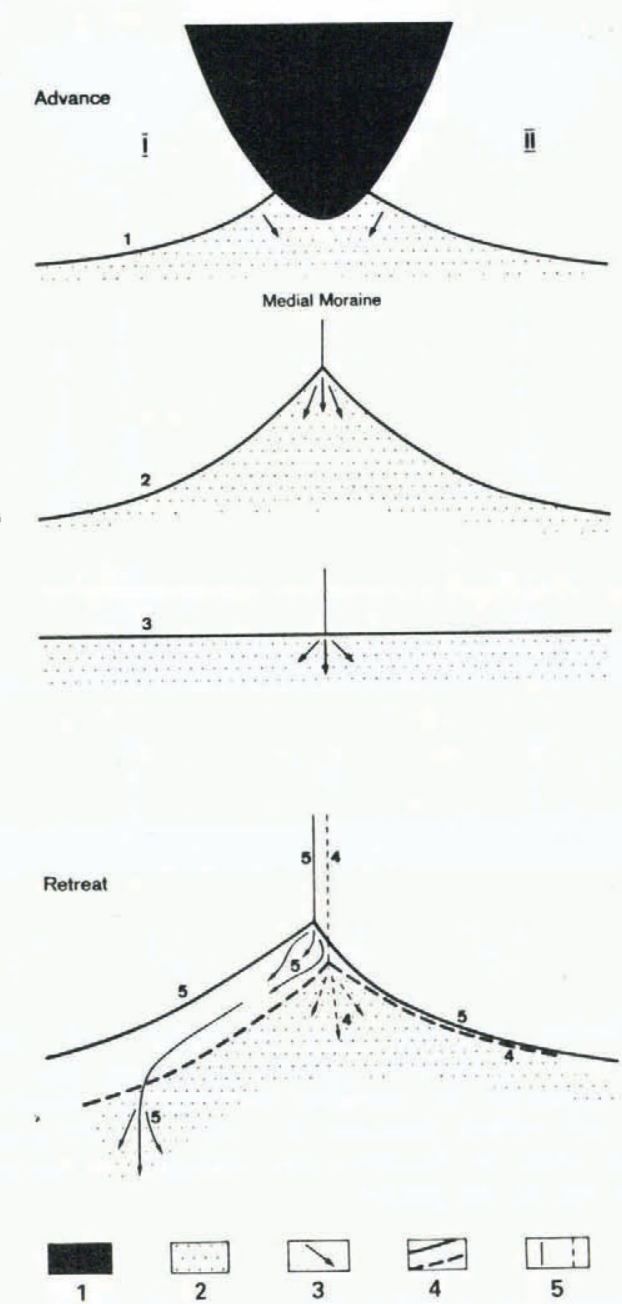

Fig. 3. Situation of the glacier margin, melt-water outlets, and medial moraines in an advancing and in a retreating composite glacier.

Stage 1: glaciers before the junction: two separated ice bodies $I$ and $I I$.

Stage 2: early stage of junction; at the contact the terminus forms an angle.

Stage 3: later stage: the angle has disappeared but the medial moraine and melt-water outlet persist at the contact between the two ice bodies.

Stages 4 and 5: development from its maximum extent (stage 4, here equivalent to stage 2) to the retreat (stage 5): ice body I diminishes quicker than ice body II; ice body II moves into the flank of ice body I, the melt-water river, flowing from the contact between both ice bodies, changes its radial flow direction (away from the glacier terminus in stage 4) to a tangential direction (along the front of the first receding ice body I (stage 5).

1. mountain; 2, sandur plain in front of the glacier; 3 , melt-water drainage; 4, glacier margins; 5, medial moraine; for 4 and 5, the position in stages, following $1-2-3,4-5$.

Confluence and separation of both glaciers demonstrate a form of geomorphological development which seems to be common in such glacier contacts (Fig. 3).

At their contact, the lateral moraines of both glaciers formed a medial moraine and the lateral melt-water rivers united to form one, which flowed from the terminus at the contact between the two ice bodies.

At first, the fronts of both glaciers formed an angle which became more obtuse during further advance. At least, the angle would have disappeared and the glacier front would have become straight like that in front of the other medial moraines of Breidamerkurjokull.

But, recession began before the angle between the two glacier fronts disappeared and it was accompanied by the following development.
The smaller glacier (Fjallsjökull) receded quicker and earlier than the larger one (Breidamerkurjokull). The glacier which receded later moved into the flank of the first one to recede, pushing the medial moraine in the direction of Fjallsjökull. The melt-water river, arising from the contact zone in front of the ice changed its radial flow direction and discharged tangentially to the ice front into the area from which Fjallsjökull had already receded.

There it built its channels, on a lower-level sandur plain, between the outermost moraine ridges of the maximum extent and the receding glacier front of Fjallsjökull, thus destroying most of the terminal moraines of the recession stages. The terminal moraines in front of the glacier which receded later (Breidamerkurjökull) are therefore better preserved.

In areas of recession, the angle of contact between the fronts of two ice bodies of different sizes of ten cannot be reconstructed, because the melt-water river, which had been directed towards the first receding glacier had already destroyed the terminal moraines of the recessional stages. Only melt-water channels are often left, and they are in fact a stronger geomorphological feature of this development than the terminal moraines themselves.

\section{TYPICAL FEATURES OF COMPOSITE GLACIERS IN PLEISTOCENE ICE SHEETS}

One of the main reasons for studying recent glaciers is to seek a better understanding of the fossil traces left by the vast ice sheets of the Pleistocene. However, most of the glaciers studied today are valley glaciers, which correspond primarily to fossil valley glaciers and not to large ice sheets covering lowlands.

Of all the recent glaciers in Europe, Breidamerkurjökul seems to be one of the best examples of a large composite glacier, which flows from the mountains to a lowland area. Its structural properties, acquired mainly in the junction areas between different feeder glaciers, still govern the behaviour of subglacial water in the lowland areas. The ice sheets of the Pleistocene, which moved over hilly ground, acquired a similar structural formation to composite glaciers, and the subglacial water was also directed by these structures.

It makes no great difference whether the hills penetrated to the glacier surface as nunataks or whether they remained covered by ice. Of importance for its influence on subglacial waterways was the structural formation near the base of the glacier.

In this sense, the structural development of composite glaciers can have some similarities to the structures of the advancing ice sheets of the Pleistocene.

In two examples, some features of Breidamerkurjökull are used as models for an explanation of fossil forms.

\section{MÜNSTERLÄNDER KIESSANDZUG - AN ESKER OF THE SAALIAN GLACIATION}

During the Saalian glaciation the North European ice sheet entered the Münsterland and left drift, ground moraine, and melt-water deposits in many places, but today they are mostly covered by younger sediments.

No long terminal moraine ridges have been left to assist the reconstruction of the ice-flow development. The distribution of erratics led Hesemann (1975) to the conclusion that the ice came from the north-east, crossing the ridge of the Teutoburger Wald. Seraphim $(1972,1973)$ found several drumlins near Gütersloh (a town in the north-eastern part of the Münsterland) which seemed to have been formed by ice flow from the north-west.

One large esker, the Münsterländer Kiessandzug, remains. This consists of a channel, cut subglacially to a depth of $10-30 \mathrm{~m}$ into the Upper Cretaceous marls and limestones, and with a length of about $80 \mathrm{~km}$ and a width of $100-700 \mathrm{~m}$. In this channel, a ridge of melt-water sand with some pebbles had accumulated and today at a number of places it penetrates through younger cover sands to the surface (Fig. 4).

The large size of this esker corresponds very well to the large amounts of subglacial water available for 


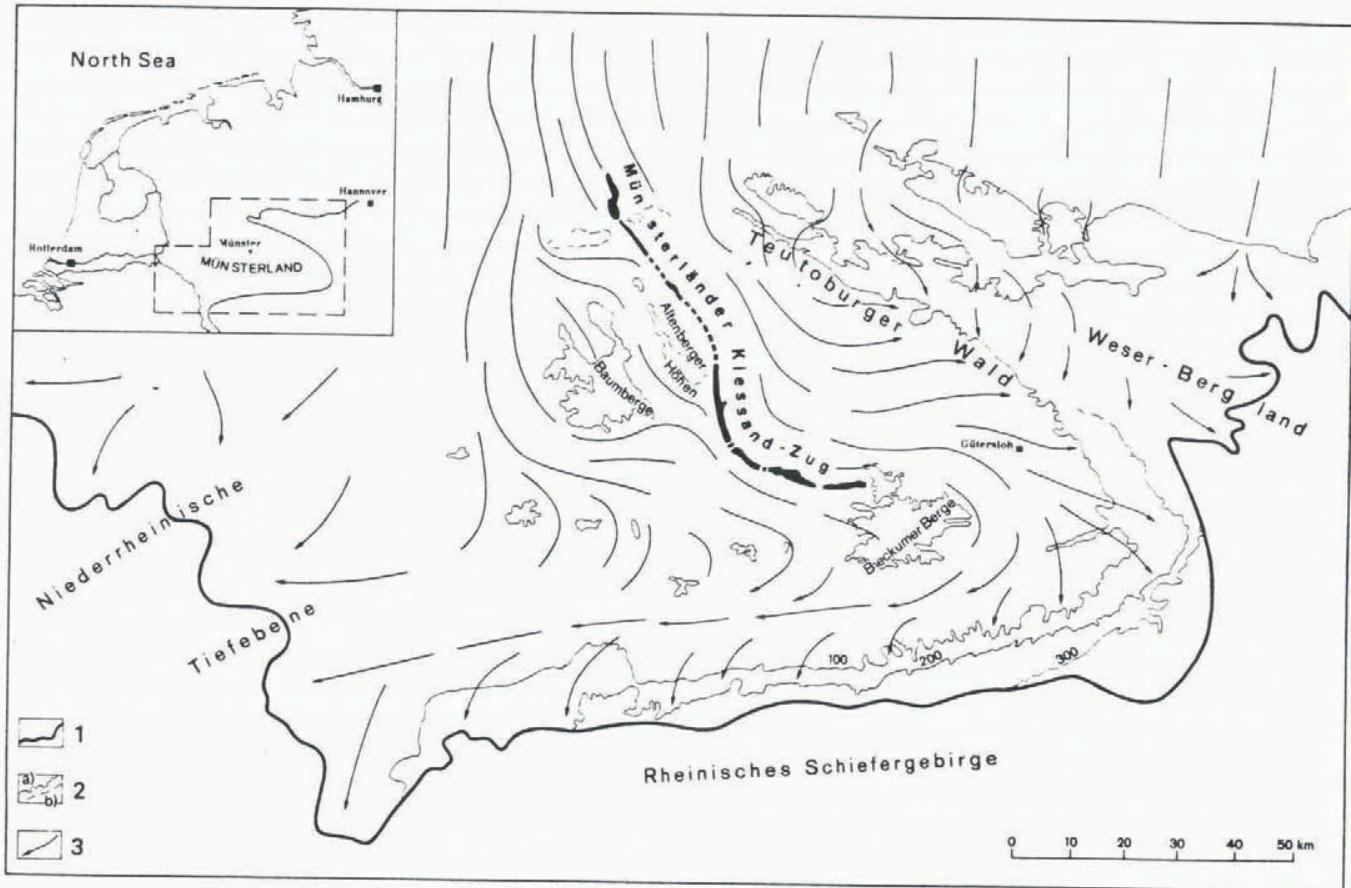

Fig. 4. Münsterland glacier of the Saalian glaciation, north-west Germany. 1, outermost ice margin; 2 , contours of the surface beneath the ice, (a) $100 \mathrm{~m}$ intervals, (b) less than $100 \mathrm{~m} ; 3$, flow direction of

drainage. The water was supplied by an ice-dammed lake east of the Teutoburger Wald ridge. This lake, nourished not only by melting ice but even more so by the discharge of the Weser and Elbe Rivers catchment areas, had been dammed since the time the ice sheet, approaching from the north, met the north-western end of the Teutoburger Wald ridge.

Where the ice surmounted the low hills on the northern border of the Münsterland it was water-free but, where it entered the valleys, it was accompanied by large amounts of water at its base. It formed large subglacial channels below the Ems Plain; these channels are now covered by younger sediments and are not visible today. But, subglacial water also entered the valley of the Steinfurther $\mathrm{Aa}$, and on its way south from there developed the channel of the Münsterländer Kiessandzug. At first, the course of the

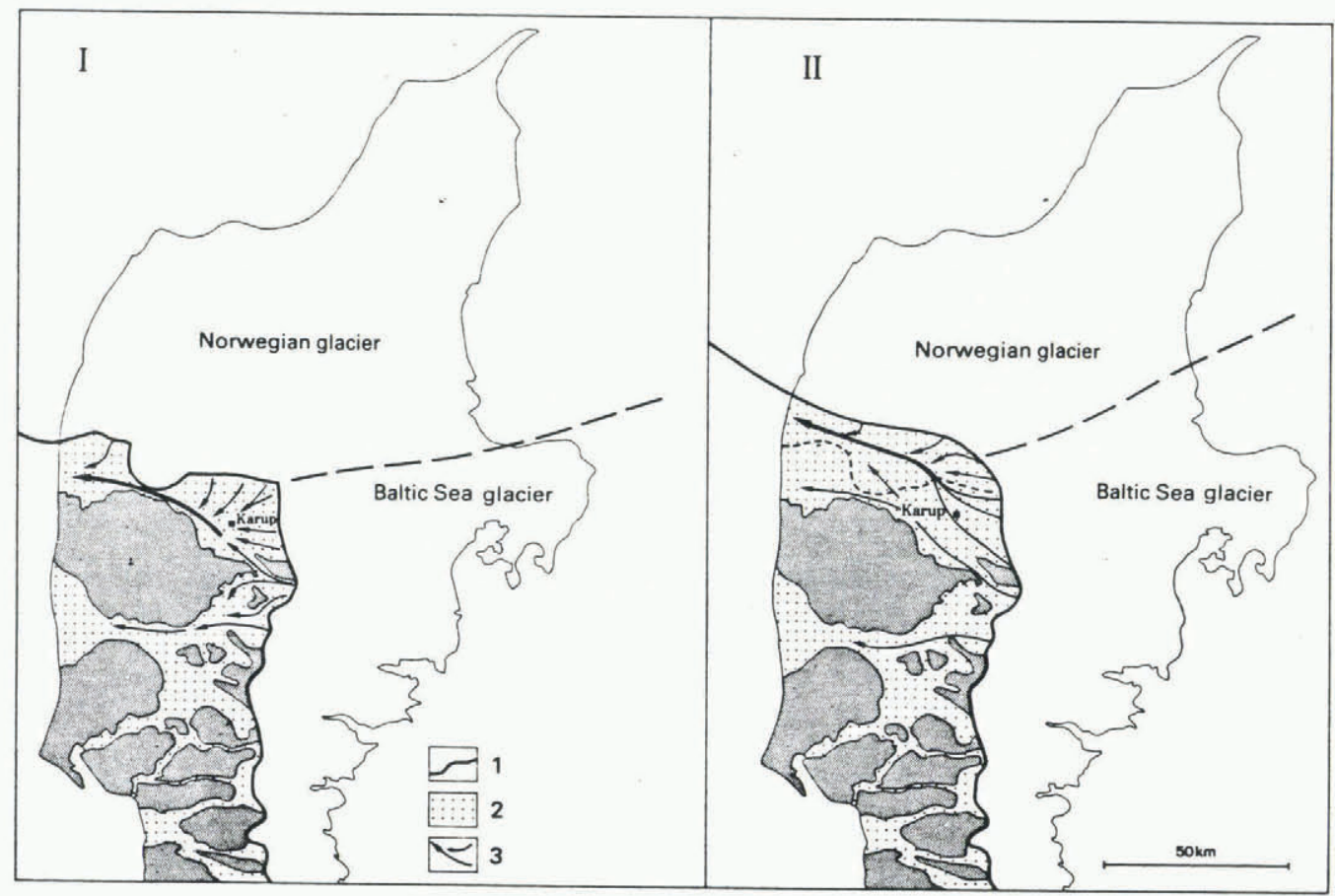

Fig. 5. Junction between the Norwegian glacier and the Baltic Sea glacier during the Weichselian glaciation, Jutland (Denmark). The angle at the outermost glacier terminus is well preserved by moraines and the Karup Sandur; the angle of the recession stage cannot be reconstructed, because the terminal moraines of the retreat are far too destroyed. The melt-water river, arising at the head of the Karup Sandur, drained radially over that sandur (away from the ice); during recession it changed to a tangential flow along the retreating ice front of the Norwegian glacier. 1, ice limit; 2, sandur; 3 , melt-water outlets and flow direction. 
channel, and of the ice flow, was directed towards the south, indicating spreading of the ice body to the east of it. This ice body east of the Münsterlănder Kiessandzug entered the Münsterland through the Ems Valley plain. It was more extensive than the ice body entering from the west of the esker.

On its way south this esker has some small bends, which may have been caused by the influence of the morphology of the terrain on the ice flow. In the area of the town of Münster, the esker turns to the east, indicating a marked diminution of the eastern ice body. The left flank of this ice body moved along the slope of the Teutoburger Wald ridge, where several incisions in the ridge acted as overflows from the ice-dammed lake behind that ridge. The overflow water caused intense melting of the left flank of the Münsterland glacier.

Yet, another point, a comparison between Breidamerkurjökull and the Münsterland glacier is of interest.

At Breidamerkurjökull, the eskers are not situated in the channels occupied by the main subglacial rivers; the latter are marked by deep erosion to peripheral lakes along the glacier terminus. The eskers are usually situated near the medial moraine D-E (Fig. 1) without large lakes at the terminus, and in a more "peripheral" position to the subglacial drainage and on a subglacial water divide.

The site of the Münsterländer Kiessandzug esker was not the main subglacial water flow below the Münsterland glacier, for even larger channels are situated east of that esker below the plain near the town of Rheine in the Ems Valley. Also, the Münsterlănder Kiessandzug is situated in a peripheral position in relation to the subglacial drainage of the Münsterland glacier.

JUNCTION BETWEEN THE NORWEGIAN AND THE BALTIC SEA GLACIERS IN JUTLAND (DENMARK) DURING THE LAST GLACIATION

Similar sequences in geomorphological development, as at the junction between Breidamerkurjökull and Fjallsjökull, took place at the junction between other Icelandic glaciers: Skaftafellsjökull and Svinafellsjökull, and the now separated branches of Heinabergsjökull (Thome, 1972).

On a much larger scale, it also occurred at the junction between the Norwegian glacier and the Baltic Sea glacier of the North European ice sheet during the (last) Weichselian glaciation (Fig. 5).

During its maximum extent, the terminus of the Norwegian glacier and the Baltic Sea glacier formed an angle at their contact in northern Jutland, where one of the largest melt-water rivers from that ice sheet was responsible for the accumulation of the well-known Karup Sandur. When the recession began, the smaller Norwegian glacier left its outermost moraine ridges first. The melt water, escaping from the contact zone, followed and formed deeper river beds between the higher surface of the Karup Sandur and the receding front of the Norwegian ice. Also, the receding glacier front is not well preserved here by moraine ridges, but only melt-water channels show a geomorphological development similar to that at Breidamerkurjokull and other Icelandic glaciers. During the recession, there was wandering of the melt-water channels from a radial drainage pattern in the contact area to the front of the glacier that receded first. A spreading of the Baltic Sea glacier into the flank of the Norwegian glacier can also be assumed. The mixing of boulders carried by both glaciers (Milthers, 1942) in that part of the area may also be due to these movements.

\section{ACKNOWLEDGEMENTS}

The author is indebted to the late Professor Dr S. Thorarinsson (Reykjavik) and Flosi Björnsson (Kvisker), Iceland, for advice on the journeys to Vatnajökull, to O.L. Hughes (Geological Survey of Canada) on a journey to north-western Canada, to the Landschaf tsverband Rheinland, Cologne, West Germany, for a grant (Albert Steeger Stipendium) for the 1966 journey to Vatnajökull. Figure 1 was taken partly from air photographs of Landmaelinger Islands and the Department of Geography, University of Glasgow.

\section{REFERENCES}

Ahlmann, H.W:son. 1938. Land of ice and fire. London, Kegan Paul, etc.

Eythórsson, J. 1949. Variations of glaciers in Iceland, 1930-47. Journal of Glaciology, Vol. 1, No. 5, p. 250-52.

Hesemann, J. 1975. Geologie Nordrhein-Westfalens. Bochumer Geographische Arbeiten 2.

Jonsson, J. 1955. On the formation of frontal glacial lakes. Geografiska Annaler, Årg. 37, Ht. 3-4, p. 229-33.

Milthers, K. 1942. Ledeblokke og Landskabsformer i Danmark. Danmarks Geologiske Undersøgelse. II Række, Nr. 69.

Price, R.J. 1969. Moraines, sandar, kames and eskers near Breidamerkurjökull, Iceland. Institute of British Geographers. Transactions, No. 46, p. 17-43.

Seraphim, E.T. 1972. Wege und Halte des saalezeitlichen Inlandeises zwischen Osning und Weser. Geologisches Jahrbuch, Reihe A, 3.

Seraphim, E.T. 1973. Drumlins des Drenthe-Stadiums am Nordostrand der Westfălischen Bucht. Osnabrücker Naturwissenschaftliche Mitteilungen 2, p. 41-87.

Thome, K.N. 1972. Asymmetries in glacier-structure and their influence on glacier-movement and glacier-deposits. $24 \mathrm{th}$ International Geological Congress, Montreal. Proceedings, Section 12, p. 198-211.

Thorarinsson, S. 1943. Oscillations of the Iceland glaciers in the last 250 years. Geografiska Annaler, Ȧrg. 25, Ht. 1-2, p. 1-54.

Todtmann, E.M. 1960. Gletscherforschungen auf Island (Vatnajökull). Universität Hamburg. Abhandlungen aus dem Gebiet der Auslandskunde, Bd. 65, Reihe C, Bd. 19. 